SILVIA W. DE GROOT

\title{
NAAR AANLEIDING VAN HET HERDRUKKEN VAN BENOIT'S VOYAGE A SURINAM
}

\author{
Voyage à Surinam. Description des possessions \\ néerlandaises dans la Guyane, door P. J. Benoit. \\ Oorspronkelijke uitgave Brussel I839; herdruk \\ S. Emmering, Amsterdam 1967. [Los bijgevoegd \\ 'Summary of the description by P. J. Benoit with \\ annotations by Silvia W. de GroOt,' 12 bladz. in \\ hetzelfde formaat, $40 \times 29 \frac{1}{2} \mathrm{~cm}$ ].
}

Bij de antiquair-uitgever S. EMmering verscheen in december I967, in zijn serie herdrukken van 'Important and rare Americanum' 1 een facsimile van het in I839 in Brussel verschenen werk van J. P. Benort, Voyage à Surinam. Het zeer fraaie en interessante plaatwerk is opnieuw uitgegeven als een foto-lithografische herdruk. Dit procédé heeft een bijzonder geslaagd resultaat opgeleverd: de reproducties in de oorspronkelijke afmeting van de 99 litho's hebben niets aan schakering en scherpte verloren, terwijl het gebruikte papier het oorspronkelijke in kleur en kwaliteit zo dicht mogelijk nadert. Het is een goede gedachte geweest dit boek, dat bijna niet meer te koop is, weer verkrijgbaar te maken voor geïnteresseerden. BENoIT's werk is namelijk niet alleen van kunstzinnige maar ook van historische waarde door zijn platen, vooral door zijn beschrijving van het leven in Suriname in het begin van de vorige eeuw. Door de fascinerende, uiteraard directer aansprekende litho's, is het belang van de tekst niet altijd onderkend. Die is echter even, zo niet meer belangwekkend en instructief. De prenten geven een romantisch en idyllisch beeld, van de schoonheid van het oerwoud, de naïve en vrolijke zwarten, de waardige blanken, de fraaie en vriendelijke huizenbouw, weliswaar met verfrissende ironie gebracht, maar

1 In 1965 verschenen als eerste herdrukken in deze serie: Kurzgefasste neger-Englische Grammatik (Bauzen, 1854 ) en Deutschnegerenglisches Wörterbuch (Löbau I 856) van de missionaris H. R. WULLSCHLÄGEL. In voorbereiding zijn: Essai Historique sur la Colonie de Surinam van DAvid DE IshaK CohEN NASSY (Paramaribo, 1788), en Nachricht von Surinam und seine Einwohnern van C. QUANDT (Görlitz, 1807). 
zij geven een gedeeltelijke waarheid. De tekst, die door BENoIT zelf kennelijk ook van groot belang werd geacht, en waarvan de platen ook volgens hem letterlijk ter illustratie dienden, geeft een realistischer en veel meer omvattend beeld van Suriname, gezien door een Ige eeuwer. De verhoogde belangstelling voor de cultuurhistorische achtergronden van gedekoloniseerde gebieden, het inzicht dat de kennis van die geschiedenis nodig is voor, en betrokken moet worden bij het bestuderen van die gebieden in deze tijd, maakt dat deze herdruk zeker in een behoefte voorziet. Door het boek te voorzien van een los ingevoegde (door schrijfster dezes) bewerkte Engelse tekst wordt het bovendien voor een groter dan alleen Frans lezend publiek toegankelijk gemaakt, terwijl de toegevoegde annotaties historische en plaatselijke feiten toelichten en verduidelijken.

Pierre Jacoues Benoit werd in $\mathrm{I} 782$ in Antwerpen geboren en stierf in Brussel in I854. Hij werd opgeleid tot goudsmid, maar tekenen en reizen hadden zijn persoonlijke voorkeur. Hij begon daar zeer jong mee en had op zijn twintigste Italië, Zwitserland, Oostenrijk, Beieren en Pruisen al doorgetrokken. Hij was zeer intelligent en leerde de talen van de landen waar hij doortrok of woonde. Hij woonde een tijd op Helgoland waar hij handel dreef en werd in Parijs restaurateur van schilderijen (aan het Louvre) nadat hij handelsagent en kapitein van een koopvaardijschip was geweest. Hij leidde nu eens een luxueus, dan weer een bohèmeleven, afhankelijk van zijn verdiensten, in het eerste geval een graag geziene gast in elegante salons waar hij zelfs als incroyable' betiteld werd, in het andere geval schilder van waardeloze schilderijen of affiches.

Op rijpere leeftijd maakte BENOIT reizen naar de Nederlandse koloniën in Oost- en West-Indië. In Suriname tekende hij een rijke en fraaie collectie prenten. Deze prenten werden door de beroemde lithografen MADOU en LAUTERS op steen gebracht en gedrukt en de tekst die BENOIT erbij schreef werd bewerkt door 'un littérateur distingué'. BENOIT is van plan geweest nog een werk te publiceren. De prospectus ervan is verschenen maar het boek niet. Het zou heten: 'Voyages et aventures de Pierre Jacques Benoit, auteur du Voyage à Surinam.'

Hoewel noch in BENorT's werk noch elders vermeld staat wanneer en waarom hij in Suriname was, valt dit toch wel op te maken uit voorvallen die hij beschrijft en opmerkingen die hij maakt. Waarschijnlijk heeft hij in I83I het land bezocht, en afgaande op 
de vele reizen die hij naar het binnenland maakte en de tijd die hij verbleef bij Indianen en Bosnegers en in de stad Paramaribo, moet hij er vele maanden hebben doorgebracht.

Volgens BENOIT zelf trok hij naar Suriname uit pure zucht tot het bereizen van vreemde landen, uit nieuwsgierigheid naar het onbekende, elke geboren reiziger eigen. Hij ondernam de reis op eigen initiatief, zonder enige hulp, en zonder enige andere steun dan zijn eigen wilskracht. Hij laat niet na te wijzen op de vele moeilijkheden, gevaren en ontberingen die hij heeft weten te overwinnen. Zijn doel was echter ook: een kolonie te beschrijven waarvoor niet genoeg belangstelling bestond, terwijl wat men onder het Nederlands bewind bereikt had onder zeer moeilijke omstandigheden, verbazing- en indrukwekkend was.

Hoewel hij zegt zich te hebben beperkt tot het geven van een schets, het aanduiden van de meest saillante punten, terwijl er over elk onderwerp een dik boek te schrijven zou zijn, eist hij toch de eer voor zich op het meest complete en consciëntieuze boek over Suriname geschreven te hebben tot nu toe (I839). Dit meende hij letterlijk: wat tot nog toe over Suriname geschreven was, vond BENOIT, was incompleet, fout, en bevooroordeeld. Als voorbeeld noemt hij STEDMAN die, vond hij, te zeer de nadruk legde op het helse bestaan der negers en gruwelverhalen vertelde die door volgende schrijvers werden overgenomen. BENOIT heeft die zelfde negers met zachtheid zien behandelen. Met instemming citeert hij een Franse tijdgenoot, die verklaart dat de kolonisten van hun macht geen misbruik maken en vindt dat de Nederlandse kolonie gunstig afsteekt bij Frans Guyana.

BENOIT behoorde tot de tegenstanders van de afschaffing der slavernij. Zijn argumenten waren dat Europa niet meer buiten de producten van de plantages kon, dat voor het bewerken van die plantages in Zuid-Amerika noch genoeg mankracht noch genoeg werkvee voorhanden was. Men moest dus de negerslaven wel gebruiken en het zou minstens nog een eeuw duren voor men door een nieuwe wijze van productie de 'armen der Afrikanen' zou kunnen missen. Bij deze instelling tegenover de slavernij paste een ander argument, dat BENOIT geregeld te berde brengt: de slaveneigenaars in Suriname behandelden hun slaven uit menslievendheid én welbegrepen eigenbelang helemaal niet zo slecht als door voorstanders van de afschaffing van slavernij werd beweerd.

Zijns ondanks kon BENOIT er echter niet aan ontkomen soms iets van het harde en wrede dagelijkse bestaan der slaven te be- 
schrijven om te verklaren waarom de slaven wegliepen, in opstand kwamen en van haat jegens de blanken vervuld waren.

$\mathrm{Bij}$ de beschrijving van dansfeesten is de verklaring voor de hartstocht waarmee de slaven er zich aan overgaven, dat zij een tijdelijke ontsnapping zochten uit hun ellendig bestaan: "zij vergaten daarbij spade en zweep, vermoeidheid en verdriet." Op de feesten die hij meemaakte vonden, schreef hij, nooit ongeregeldheden plaats, maar er was dan ook een bastiaan bij die de orde met een zweep bewaarde!

$\mathrm{Na}$ in zijn eerste hoofdstuk een overzicht van de geschiedenis van Suriname gegeven te hebben, beschrijft BENOIT in het tweede zijn aankomst in dit land. Hij raakt, na maanden niets anders dan zee gezien te hebben, in vervoering over bomen, planten, bloemen, vogels en vlinders; kleuren en geuren brengen hem in verrukking. Hij beschrijft de geografie van Suriname, het verdedigingssysteem tegen buiten- en binnenlandse (marrons) vijanden, de plantages en de stad Paramaribo. In hoofdstuk drie beschrijft hij de bewoners van deze stad en geeft zijn mening over de handel, wandel en karakter van de bewoners, de creolen: levendig en intelligent, maar laks en lui, en bang voor werk. Ook de Europeanen worden overigens indolent genoemd, als gevolg van het klimaat. Creolen en Europeanen mochten elkaar niet. De reden was, zegt BENoIT, dat de eersten met lede ogen aanzagen dat de laatsten zich van de beste banen meester makten en het grootste deel van de handel in bezit hadden. Hij vond dat men te veel waarde aan afstamming hechtte en onderscheid tussen kinderen van blanken, creolen, negers en slaven makte, met als gevolg een scheiding der klassen en slechte verhoudingen. Hij noemde de Surinamers losbandig en zedeloos: ze verdeden een groot deel van hun tijd met feestvieren en 'traden de echtelijke trouw met voeten' door er creoolse maitressen op na te houden. Als beste middel om de gezondheid te bewaren in het warme en vochtige klimaat raadt BENOIT aan alle excessen te vermijden en verder geen aandacht aan de gezondheid te besteden. Hartstocht, verdriet, angst zijn fataal, zegt hij; zedelijk gedrag, onverschilligheid en vrolijkheid houden gezond.

In hoofdstuk vier beschrijft hij een tocht de Surinamerivier op, de Joden-Savanne, die nog floreerde, en de plantages die hij passeert. Hij uit zijn verbazing en bewondering over de wilskracht en vindingrijkheid der kolonisten die van dit land, in een moeilijk terrein en een slecht klimaat een deel tot een rijk gecultiveerd gebied hebben gemaakt. Hij beschrijft de opbouw, de werking, de producten van de plantages, de uitvoer en de invoerproducten van het land, de houtsoorten, de dieren.

In hoofdstuk vijf beschrijft hij wat hij volgens zijn zeggen met eigen ogen bij Indianen heeft meegemaakt. (Hij wilde niet putten uit 'leugenachtige of foute geschriften'). Hoewel ze van nature te goeder trouw zijn, meent BENOIT, hebben de oorlogen die ze tegen wrede indringers moesten voeren hen bevreesd, listig en wantrouwend gemaakt. Hij geeft een eenvoudig en oppervlakkig relaas van zijn bevindingen over hun leefwijze. Hij beschrijft hen als de gelukkige wilde, weliswaar verstoken van de goede zegeningen van 'onze' beschaving, maar ook van de 
negatieve kanten ervan. $\mathrm{Zij}$ leven in volledige vrijheid en zijn tevreden met wat de natuur hen biedt. Hij laat hierop echter volgen, dat zij zich wel te beschermen hebben tegen de vele gevaren en moeilijkheden die hen omringen en bedreigen bij elke pas die zij doen, en daarbij hun bijzonder ontwikkeld instinct hard nodig hebben. Van dat onfeilbare instinct geeft BENOIT in hoofdstuk zes een sterk staaltje.

Hoofdstuk zeven behandelt het leven van de negerslaven. BENOIT vertelt summier iets over huwelijks-, geboorte-, en begrafenisritueel en over hun religieuze bijeenkomsten, waarbij zij, zegt hij 'wreder dan wilde beesten' zijn en waarbij zich hun haat uit voor de blanken. De planters zijn bang voor de resultaten van deze uitbarstingen en gaan er zelfs toe over offerandes te laten leggen onder de heilige boom, waar die bijeenkomsten worden gehouden. Conform aan zijn opvatting dat de slaven goed behandeld werden, vindt men althans in dit hoofdstuk van hem geen woord over de wrede behandeling die de door hem geconstateerde haatgevoelens zou kunnen toelichten. Als hij een vonnis vermeldt waarbij een slaaf wordt veroordeeld tot ophanging en afslaan van het hoofd is dit om de 'onwetendheid en bijgelovigheid' van de veroordeelde te illustreren, die geen bezwaar maakte tegen de strop, maar wel tegen het afslaan van zijn hoofd, want hoe zou hij zonder hoofd zijn 'Mama-Sneki' (Slangengod) kunnen antwoorden?

In hoofdstuk acht beschrijft Benort de geschiedenis van de Bosnegers, zoals hij die in (onvermelde) bronnen vond. Zelf maakte hij hoogstwaarschijnlijk een - in een artikel van de vredescontracten toegezegde - vierjaarlijkse geschenkenuitdeling van het gouvernement aan de Bosnegers mee. Aangezien hij hierbij vermeldt dat het fungerende opperhoofd TroBBI heette, is hieruit op te maken (en uit andere bekende data van geschenkenuitdelingen) dat dit in 1831 moet zijn geweest. Dit is dan één van de indicaties dat BENoIT omstreeks dat jaar in Suriname was.

Voor de godsdienst van de bosnegers verwijst BENorT naar de plantageslaven.

Hoofdstuk negen tenslotte behandelt de toenmalige economie van het land, waarin BENOIT opnieuw zijn bewondering voor het gepresteerde uit, en hoewel hij inzag dat de welvaart minderde, was hij optimistisch gestemd over Surinames toekomst. 